\title{
AKUNTABILITAS PENGELOLAAN KEUANGAN KAMPUNG DALAM PEMBERDAYAAN MASYARAKAT DI DISTRIK BENAWA KABUPATEN YALIMO PROVINSI PAPUA
}

\author{
Hendrik Wakman*); Sampara Lukman; Irawan \\ Pascasarjana Institut Pemerintahan Dalam Negeri Jakarta \\ *)email: hendrikwkmnipdn32@gmail.com
}

Paper Accepted: 30 Juni 2021 Paper Reviewed: 01-07 Juli 2021 Paper Edited: 08-15 Juli 2021 Paper Approved: 18 Juli 2021

\begin{abstract}
ABSTRAK
Penelitian ini membahas tentang Akuntabilitas Pengelolaan Keuangan Kampung Dalam Pemberdayaan Masyarakat Di Distrik Benawa Kabupaten Yalimo Provinsi Papua. Tujuan penelitian bermaksud untuk mengetahui bagaimana Akuntabilitas Pengelolaan Keuangan Kampung Dalam Pemberdayaan Masyarakat di Distrik Benawa Kabupaten Yalimo Provinsi Papua. Indikator Akuntabilitas Pengelolaan Keuangan Kampung Dalam Pemberdayaan Masyarakat di Distrik Benawa Kabupaten Yalimo Provinsi Papua penulis mengacu pada indikator Akuntabilitas Keuangan dari LAN \& BPKP RI (2000). Ada Tiga indikator dari pengukuran Akuntabilitas Pengelolaan Keuangan tersebut antara lain: 1) Akuntabilitas Keuangan, 2) Akuntabilitas Manfaat, dan 3) Akuntabilitas Prosedur. Untuk mendukung tujuan tersebut maka digunakan metode kualitatif, dimana penelitian menggunakan wawancara untuk menggali informasi secara terbuka sehingga informasi dianalisis menggunakan Triangulasi data yang terdiri dari Reduksi Data, Penyajian Data, Penarikan Kesimpulan. Dari penelitian tersebut, didapatkan hasil bahwa alur pelaporan keuangan kampung sudah sesuai dengan mekanisme yang diatur oleh Permendagri RI Nomor 37 Tahun 2017 tentang Pengelolaan Keuangan Kampung meskipun mekanisme tersebut selalu terlambat dilaksanakan. Faktor-faktor penghambat Akuntabilitas Pengelolaan Keuangan Kampung Dalam Pemberdayaan Masyarakat di Distrik Benawa Kabupaten Yalimo Provinsi Papua antara lai 1) sumber daya manusia, 2) Anggaran, 3) Sarana dan prasarana. Hasil analisis terhadap upaya yang dilakukan dalam mengatasi faktor penghambat adalah dengan peningkatan sumber daya manusia yang bertujuan agar Proses Akuntabilitas pengelolaan keuangan kampung berjalan cepat dan juga didukung oleh sarana dan prasarana yang memadai dalam melakukan supervisi terhadap pengelolaan keuangan kampung di Distrik Benawa.
\end{abstract}

Kata Kunci : Akuntabilitas, Pengelolaan Keuangan, Kampung,

Pemberdayaan Masyarakat

\section{PENDAHULUAN}

\section{Latar Belakang Masalah}

Negara Indonesia merupakan Negara Kesatuan berbentuk Republik yang terdiri dari 34 Provinsi, 415 Kabupaten dan 93 Kota.1 Tiaptiap daerah Provinsi, Kabupaten dan Kota memiliki Pemerintah Daerah yang dibentuk untuk mengurusi pemerintahan skala lokal. Besarnya jumlah pemerintahan yang diurusi, menjadi tantangan tersendiri untuk dikelola secara maksimal. Oleh karena itu, perlu kiranya suatu sistem pengorganisasian manajemen pemerintahan yang baik dalam pengaturan wilayah-wilayah dalam ruang lingkup Negara Kesatuan Republik Indonesia. Di era reformasi, perubahan mendasar telah terjadi dalam tata kelola pemerintahan yang semula sentralisasi bergeser menjadi desentralisasi. Peran pemerintah pusat semakin dikurangi dan memberikan peluang bagi daerah untuk mengurus rumah tangganya sendiri secara 
mandiri. Hal ini juga didasari pada amandemen IV UUD 1945 pasal 18 tentang Pemerintah Daerah

Perjalanan otonomi daerah di Indonesia sejak era reformasi terlihat semakin menjauh dari tujuan awal. Disparitas pembangunan antar wilayah di Indonesia semakin terbuka lebar khususnya wilayah Desa/kampung dengan wilayah perkotaan yang masih terjadi kesenjangan. Pembagian alokasi anggaran daerah seringkali didasari oleh 3 politik anggaran dalam membagi kue pembangunan. Keberadaan desa/kampung biasanya yang mengalami perbedaan perlakuan dengan ketidakberdayaannya dalam politik anggaran. Tekanan ini berpeluang menempatkan desa/kampung selalu berada dalam ketertinggalan dan keterbelakangan secara permanen

Permasalahan klasik yang membelenggu desa/kampung adalah kemiskinan dan keterbelakangan. Dalam upaya mengejar ketertinggalan, desa/kampung harusnya dibangun tidak hanya fokus pada infrastruktur, akan tetapi aspek sumber daya manusia desa/kampung menjadi prioritas untuk dikembangkan agar mampu bersaing dengan masyarakat lainnya. Kemiskinan dan keterbelakangan yang dialami desa/kampung, tidak diimbangi dengan tata kelola pemerintahan yang baik oleh pemerintah desa/kampung.. Fakta menyatakan bahwa masih terjadi ketimpangan pembangunan antara wilayah Desa/kampung dan perkotaan sebagai akibat salah kelola penggunaan anggaran termasuk buruknya pengelolaan keuangan di desa/kampung. Pengelolaan keuangan desa/kampung yang buruk juga terjadi di Kabupaten Yalimo berujung pada tersangkutnya Kepala kampung Nungkere terkait kasus penyalahgunaan APBDesa/kampong. peristiwa tersebut memberikan gambaran bagaimana pengelolaan keuangan desa/kampung yang buruk di Distrik Benawa Kabupaten Yalimo dalam beberapa tahun terakhir. Hal ini merupakan tanggungjawab pengelola APBDesa/kampung itu sendiri yaitu pemerintah desa/kampung dan juga DPMPK selaku pembina untuk berbenah memperbaiki pengelolaan keuangan desa/kampung mulai dari tahapan perencanaan dan penyusunan, pelaksanaan dan pertanggungjawaban sehingga akuntabilitas pemerintah desa/kampung baik prosedural maupun substansial bisa terpenuhi.

Pemerintah Kabupaten Yalimo selaku pembina penyelenggaraan pemerintahan desa/kampung mendelegasikan tanggungjawab pembinaan kepada DPMPK yang didasari oleh
Peraturan Bupati Yalimo Nomor 40 Tahun 2017 tentang penjabaran tugas pokok dan fungsi Dinas Pemberdayaan Masyarakat, Pemerintahan kampung, fungsi pembinaan penyelenggaraan pemerintahan desa/kampung dijalankan oleh Bidang Pemerintahan kampong. Peranan DPMPK dalam pengelolaan keuangan desa/kampung bertindak sebagai pembina menjalankan fungsi pemberian pedoman, bimbingan, supervisi, konsultasi, pendidikan, pelatihan serta penelitian dan pengembangan. Sementara dari sisi akuntabilitas pengelolaan keuangan desa/kampung bagi kampungkampung se Distrik Benawa menunjukkan telah terjadi penyimpangan yang dilakukan oleh aparatur kampung. Penyimpangan tersebut berupa penggelapan keuangan kampung yang tidak bisa dipertanggungjawabkan

\section{Identifikasi Masalah}

Berdasarkan latar belakang yang
dikemukakan di atas maka penulis mengidentifikasi masalah yang terjadi pada kondisi riil lapangan adalah :

1. Kurangnya penjelasan mengenai pedoman penyusunan Rencana Pembangunan Jangka Menengah kampung (RPJMKampung) oleh DPMPK Kabupaten Yalimo.

2. Kurangnya koordinasi antara pemerintahan kampung dengan DPMPK dalam penyusunan Rancangan Peraturan Desa/kampung tentang Anggaran Pendapatan Belanja kampung (APBkampung) di tingkat kabupaten.

3. Kurangnya sumber daya manusia yang menangani urusan pemerintah kampong di DPMPK Kabupaten Yalimo.

4. Pendampingan pada tahapan pelaksanaan pengelolaan keuangan kampung oleh DPMPK hanya dilakukan melalui sosialisasi.

5. Konsultasi pengelolaan keuangan kampung oleh pemerintah kampung dengan DPMPK seringkali dijawab dengan jawaban ambigu.

6. Masih ditemui penyimpangan pengelolaan keuangan kampung oleh aparatur kampung.

\section{Pembatasan Masalah}

Berdasarkan latar belakang dan masalahmasalah yang teridentifikasi, maka untuk memperjelas fokus penelitian, penulis 
membatasi masalah pada peranan DPMPK dalam membina pengelolaan keuangan kampung dalam kaitan dengan akuntabilitas keuangan kampung-kampung Distrik Benawa Kabupaten Yalimo Provinsi Papua.

\section{Perumusan Masalah}

Berdasarkan uraian pada latar belakang penelitian, identifikasi masalah dan pembatasan masalah maka pokok permasalahan yang akan diteliti dalam penelitian ini adalah :

1. Bagaimana Akuntabilitas

Pengelolaan Keuangan kampung

Dalam Pemberdayaan Masyarakat Di

Distrik Benawa Kabupaten Yalimo Provinsi Papua?

2. Faktor-faktor apa saja yang mendukung dan menghambat Akuntabilitas Pengelolaan Keuangan kampung Dalam Pemberdayaan Masyarakat Di Distrik Benawa Kabupaten Yalimo Provinsi Papua?

3. Upaya apa saja yang dilakukan dalam mengatasi Faktor Penghambat Akuntabilitas Pengelolaan Keuangan kampung Dalam Pemberdayaan Masyarakat Di Distrik Benawa Kabupaten Yalimo Provinsi Papua?

\section{Maksud dan Tujuan Penelitian Maksud Penelitian}

Sejalan dengan perumusan masalah yang dikemukakan diatas, maka maksud penelitian ini adalah untuk menggambarkan dan mendeskripsikan dalam membina pemerintah kampung ditinjau dari aspek akuntabilitas pengelolaan keuangan kampung di Distrik Benawa Kabupaten Yalimo

\section{Tujuan Penelitian}

Berdasarkan maksud penelitian tersebut di atas, maka tujuan yang ingin dicapai dalam penelitian ini adalah :

1. Untuk mengetahui dan menganalisis Akuntabilitas Pengelolaan Keuangan kampung Dalam Pemberdayaan Masyarakat Di Distrik Benawa Kabupaten Yalimo Provinsi Papua

2. Untuk mengetahui dan menganalisis Faktor-faktor apa saja yang mendukung dan menghambat Akuntabilitas Pengelolaan Keuangan kampung Dalam Pemberdayaan Masyarakat Di Distrik Benawa Kabupaten Yalimo Provinsi Papua

3. Untuk mengetahui dan menganalisis Upaya apa saja yang dilakukan dalam mengatasi Faktor Penghambat
Akuntabilitas Pengelolaan Keuangan kampung Dalam Pemberdayaan Masyarakat Di Distrik Benawa Kabupaten Yalimo Provinsi Papua

\section{Kajian Pustaka}

\section{Konsep Pemerintahan Daerah}

Pemerintahan adalah perbuatan memerintah dari semua organ yang disebut juga lembaga atau institusi negara guna mencapai tujuan negara. Untuk mencapai tujuan negara, dalam negara demokrasi pemerintah harus melindungi dan memenuhi kebutuhan masyarakat

\section{Konsep Otonomi Desa/Kampung}

Otonomi Desa/Kampung memiliki perbedaan dengan otonomi daerah. Otonomi Desa/Kampung yang dimaksud mempunyai karakteristik:
a. Sejak dulu berdasarkan hukum adat
b. Tumbuh dalam masyarakat
c. Isinya tidak terbatas
d. Bersifat elastis
e. Secara tradisional
f. Lebih bersifat nyata dan materil.

Ini menunjukan bahwa otonomi Desa/Kampung bersifat asli karena bersumber dari adat, tradisi dan budaya masyarakat yang diatur dan diurus secara terus menerus dan melembaga pada Desa/Kampung serta masyarakat di daerah tertentu. Otonomi Desa/Kampung bukan pemberian sebagaimana otonomi daerah yang mendapat delegasi kewenangan dari pemerintah melalui asas desentralisasi. Pergeseran dari otonomi Desa/Kampung yang diDesa/Kampung pemerintah merupakan antitesa yang diamanatkan oleh konsitusi dengan mengakui otonomi Desa/Kampung, namun di sisi lain pemerintah menyisipi birokratisasi yang dijalankan sekelompok orang dalam tata kelola penyelenggaraan pemerintahan Desa/Kampung. Akan tetapi perlakuan pemerintah tersebut tidak harus dipandang negatif, melalui birokratisasi Desa/Kampung diharapkan Desa/Kampung semakin memiliki daya saing dalam memberikan pelayanan kepada masyarakat sehingga kesejahteraan akan tercipta. Ketidakberdayaan Desa/Kampung pada sisi keuangan maupun dukungan sumber daya manusia menjadi alasan pemerintah untuk memperbaiki keadaan tersebut, maka dari itu timbulah kewenangan untuk melakukan pembinaan penyelenggaraan Desa/Kampung 
yang dilakukan oleh DPMPK agar penyelenggaraan pemerintahan bisa mendekati pola kerja unit pemerintah lainnya.

\section{Konsep Pemerintahan Desa/Kampung}

Mengutip Undang-undang Nomor 06 Tahun 2014 tentang Desa/Kampung, penyelenggaraan pemerintahan Desa/Kampung dilakukan oleh Pemerintah Desa/Kampung dan Badan Permusyawaratan Desa/Kampung (BPD/K) Pemerintah Desa/Kampung adalah organisasi pemerintahan Desa/Kampung yang terdiri dari :

1. Unsur Pimpinan, yaitu kepala Desa/Kampung

2. Unsur Pembantu Kepala Desa/Kampung, yang terdiri atas

a. Sekretariat Desa/Kampung, yaitu unsur staf atau pelayanan yang diketuai oleh Sekretaris Desa/Kampung;

b. Unsur Pelaksana Teknis, yaitu unsur pembantu kepala Desa/Kampung yang melaksanakan urusan teknis di lapangan seperti urusan pengairan, keagamaan dan lainlain

3. Unsur kewilayahan, yaitu pembantu kepala Desa/Kampung di wilayah kerjanya seperti Kepala Dusun.

Badan Permusyawaratan Desa/Kampung (BPD/K) merupakan struktur kelembagaan penyelenggara pemerintahan Desa/Kampung dengan sekumpulan orang yang mewakili masyarakat berdasarkan keterwakilan wilayah ditetapkan melalui musyawarah dan mufakat. $\mathrm{BPD} / \mathrm{K}$ berkedudukan sebagai unsur penyelenggara pemerintahan Desa/Kampung yang berfungsi menetapkan peraturan Desa/Kampung bersama kepala Desa/Kampung, menampung dan menyalurkan aspirasi masyarakat.

Pemerintah Desa/Kampung dipimpin oleh seorang Kepala Desa/Kampung yang mempunyai tugas menyelenggarakan urusan pemerintahan, pembangunan dan kemasyarakatan. Kepala Desa/Kampung memiliki kewajiban melaksanakan dan mempertanggungjawabkan pengelolaan keuangan Desa/Kampung dalam penyelenggaraan pemerintahan Desa/Kampung sebagaimana tertuang pada salah satu butir kewajiban kepala Desa/Kampung. Kepala Desa/Kampung dibantu oleh Pelaksana Teknis Pengelolaan Keuangan Desa/Kampung
(PTPKD) sebagaimana diamanatkan oleh Peraturan Menteri Dalam Negeri RI Nomor 37 Tahun 2007 tentang Pedoman Pengelolaan Keuangan Desa/Kampung. Pelaksana Teknis Pengelolaan Keuangan Desa/Kampung (PTPKD) adalah Perangkat Desa/Kampung yang terdiri dari Sekretaris Desa/Kampung dan Perangkat Desa/Kampung lainnya. Selain itu, kepala Desa/Kampung juga mempunyai kewajiban untuk memberikan laporan pertanggungjawaban pengelolaan keuangan Desa/Kampung sebagai bagian dari laporan penyelenggaraan pemerintahan Desa/Kampung kepada bupati/walikota, memberikan laporan keterangan pertanggungjawaban kepada $\mathrm{BPD} / \mathrm{K}$ serta menginformasikan laporan penyelenggaraan pemerintahan Desa/Kampung kepada masyarakat

Pemerintah Desa/Kampung telah diberikan kewenangan oleh peraturan perundangundangan untuk menjalankan penyelenggaraan pemerintahan termasuk pengelolaan keuangan Desa/Kampung. Dengan keterbatasan sumber daya, tentunya Desa/Kampung sangat memerlukan pembinaan dalam tata kelola pemerintahan oleh perangkat daerah (DPMPK) untuk meningkatkan kapasitas dan kapabilitas aparatur Desa/Kampung berkenaan dengan pengelolaan keuangan Desa/Kampung. Untuk itu, peran DPMPK sangat diperlukan dalam melakukan pembinaan pengelolaan keuangan Desa/Kampung agar terjadi peningkatan akuntabilitas keuangan Desa/Kampung

\section{Konsep Pembinaan Penyelenggaraan Pemerintah}

Pembinaan mengandung arti "pemberian pedoman, bimbingan, supervisi, konsultasi, pendidikan, pelatihan serta penelitian dan pengembangan. Secara konkret, pembinaan menyentuh pada proses penyelenggaraan pemerintahan dengan harapan mendapatkan hasil yang maksimal. Pembinaan dan pengawasan atas penyelenggaraan otonomi daerah dimaksudkan untuk mencapai beberapa tujuan

\section{Konsep Akuntabilitas Pemerintahan}

Akuntabilitas merupakan pengungkapan aktivitas keuangan maupun kinerja organisasi secara jujur oleh individu sebagai bagian organisasi kepada masyarakat, pemerintahan atasan ataupun penyelenggara pemerintahan setara (DPR/D). Asas akuntabilitas publik pada prinsipnya menggariskan bahwa : Siapa pun adanya, apakah dia perseorangan maupun lembaga, yang diberikan wewenang oleh publik, 
memakai dan menggunakan fasilitas dan dana yang berasal dari publik, serta melakukan tugas yang berpengaruh kepada kehidupan publik, maka dia harus memberikan pertanggungjawaban kepada publik terhadap segala sesuatu yang mereka gunakan. Tanpa adanya pertanggungjawaban, maka kekuasaan institusi publik akan sangat mungkin untuk menjadi omnipotent (berkuasa secara mutlak), omnipresent (menguasai segala hal) dan omninous (sangat jahat/menyebalkan) bagi masyarakat. Akuntabilitas pemerintahan memiliki sifat memaksa kepada penyelenggara pemerintahan untuk mempertanggungjawabkan segala sesuatu yang bersumber dari pembiayaan negara secara jujur.

$$
\text { Penyelenggaraan }
$$

Desa/Kampung sebagai sub organisasi pemerintahan terendah telah memaksa pemerintahan Desa/Kampung untuk mengungkapkan aktivitas keuangan, kinerja maupun kemanfaatan bagi masyarakat secara akuntabel.

\section{Konsep Akuntabilitas Keuangan}

Akuntabilitas keuangan dapat dimaknai sebagai pertanggungjawaban individu atas tindakannya dalam organisasi terkait penggunaan uang dan dipublikasikan kepada masyarakat dalam bentuk laporan keuanganTransparansi dan akuntabilitas merupakan sesuatu hal yang selalu berkaitan, sebab pelaksanaan akuntabilitas memerlukan adanya transparansi. Transparansi dan akuntabilitas keuangan daerah merupakan pertanggungjawaban pemerintah daerah berkenaan dengan pengelolaan keuangan daerah kepada publik secara terbuka dan jujur melalui media berupa penyajian laporan keuangan yang dapat diakses oleh berbagai pihak yang berkepentingan dengan anggapan bahwa publik berhak mengetahui informasi tersebut

\section{Konsep Pengelolaan Keuangan}

Pengelolaan keuangan harus bertumpu pada kepentingan publik (public oriented). Hal ini tidak saja terlihat pada besarnya porsi pengalokasian anggaran untuk kepentingan publik, tetapi juga terlihat pada besarnya partisipasi masyarakat dalam perencanaan, pelaksanaan dan pengawasan keuangan. Pelibatan masyarakat dalam pengelolaan keuangan menjadi penentu akuntabilitas keuangan daerah ataupun Desa/Kampung.

\section{Kerangka Pemikiran}

Penelitian ini memfokuskan pada DPMPK dalam melakukan pembinaan terhadap pemerintah Desa/Kampung mengenai pengelolaan keuangan yakni pemberian bimbingan, supervisi dan konsultasi mencakup aspek perencanaan dan penyusunan APBDesa/Kampung, pelaksanaan dan pertanggungjawaban APBDesa/Kampung. Jika DPMPK telah dilakukan secara optimal maka bisa jadi pengelolaan keuangan Desa/Kampung akan akuntabel atau sebaliknya

\section{METODE PENELITIAN}

Pada penelitian ini, penulis menggunakan desain penelitian deskriptif dengan pendekatan kualitatif yang digunakan sesuai dengan permasalahan yang akan dibahas, situasi dan kondisi dari lokasi dimana penelitian dilakukan. Teknik pengumpulan data yang digunakan dalam penelitian ini adalah dengan cara Wawancara (Interview) dan telaah dokumen.

Untuk mengolah dan menganalisis data hasil penelitian, peneliti menggunakan langkahlangkah yaitu langkah awal melakukan pengumpulan data dan informasi untuk dipilih dan diseleksi sesuai fokus penelitian. Kemudian data yang telah dipilih tersebut disajikan dalam bentuk bagan atau tabel agar mudah dipahami. Dari penyajian data tersebut, peneliti menyusun pemahaman arti dalam bentuk kalimat yang sistematis dan terpadu.Selanjutnya, langkah terakhir adalah menarik kesimpulan sementara berdasarkan data yang telah disajikan. Apabila penyajian data tersebut dirasa belum memenuhi data untuk membangun kesimpulan, maka peneliti akan melengkapi kembali data yang diperlukan kemudian mereduksinya kembali untuk menjaga validitas, sampai benar-benar ditarik kesimpulan yang kredibel.

\section{HASIL DAN PEMBAHASAN}

\section{Akuntabilitas Pengelolaan Keuangan Kampung Distrik Benawa Kabupaten Yalimo \\ Pada aspek ini mengenai keterkaitan} pengelolaan keuangan Kampung terhadap akuntabilitas keuangan Kampung, yang didekati dengan 3 (tiga) aspek akuntabilitas yaitu Akuntabilitas keuangan, Akuntabilitas Manfaat, dan Akuntabilitas Prosedur. Tiga aspek tersebut bisa menjadi tolok ukur keberhasilan pengelolaan keuangan Kampung secara subtansial.

\section{Akuntabilitas Keuangan \\ Mekanisme pelaporan Keuangan Kampung berpedoman pada Permendagri RI Nomor 37 Tahun 2017 tentang Pengelolaan Keuangan}


Kampung yang dimulai dari tahapan penyusunan dokumen pelaporan pertanggungjawaban Keuangan Kampung yang disusun oleh Sekretaris Kampung dengan memadukan data dari bendahara Kampung berupa Buku kas umum, Buku kas pembantu perincian obyek pengeluaran dan Bukti atas penyetoran PPN/PPh ke kas negara. Penyusunan laporan pertanggungjawaban tersebut disampaikan kepada Kepala Kampung untuk dibahas bersama BAMUSKAM paling lambat 1 (bulan) setelah tahun anggaran berakhir dan ditetapkan menjadi peraturan Kampung. Hasil dari laporan pertanggungjawaban APBKampung yang telah ditetapkan menjadi peraturan Kampung tersebut disampaikan paling lambat 7 (tujuh) hari kepada Bupati. Mekanisme pelaporan Keuangan Kampung yang dijalankan oleh Kampung-Kampung se Distrik Benawa sudah melewati tahapan tersebut. Hanya saja mekanisme tersebut selalu terlambat dilaksanakan.

Hal ini terbukti ketika ditemukan dokumen pertanggungjawaban Keuangan Kampung sepanjang tahun 2015-2020 baru dibuat dan disampaikan pada bulan April setelah tahun anggaran berakhir. Padahal ketentuan yang diatur pada Permendagri RI Nomor 37 Tahun 2017 tentang Pedoman Pengelolaan Keuangan Kampung mewajibkan Kampung membuat laporan pertanggungjawaban APBKampung paling lambat 1 (satu) bulan setelah anggaran berakhir dan menyampaikan kepada Bupati melalui Kepala Distrik paling lambat 7 (tujuh) hari. Bentuk pelaporan keuangan kampung, masing-masing kampung se distrik Benawa memiliki format tersendiri dikarenakan panduan berupa Permendagri maupun arahan dari DPMPK tidak memberikan format yang terstandarisasi.

Berdasarkan Laporan Hasil Pemeriksaan Inspektorat pada tahun anggaran 2018 kepada Kampung trikora, Nungkere dan Pepera, Nomor : 700/123/Inspek/2019 tanggal 29 Oktober 2019 memuat rincian pemeriksaan yang disajikan dalam bentuk tabel 1. dibawah ini.

Tabel 1

Hasil Temuan Penyimpangan Pengelolaan Keuangan Kampung pada Tahun 2017 pada Kampung Trikora, Nungkere dan Pepera

\begin{tabular}{|c|c|c|}
\hline No. & Kampung & Hasil Temuan \\
\hline 1 & 2 & 3 \\
\hline 1. & Trikora & $\begin{array}{l}\text { 1. Terdapat selisih negatif antara saldo buku dengan saldo kas pada } \\
\text { saat pemeriksaan sebesar Rp. 4.749.961,- dikarenakan terdapat } \\
\text { pinjaman tunai beberapa orang anggota BAMUSKAM dan } \\
\text { perangkat Kampung. } \\
\text { 2. Realisasi penerimaan Kampung masih nihil. Hal ini disebabkan } \\
\text { penerimaan asli Kampung tidak dilaksanakan melalui rekening } \\
\text { Kampung. } \\
\text { 3. Laporan pertanggungjawaban berkala belum dibuat pada saat } \\
\text { pemeriksaan. } \\
\text { 4. Terdapat } 24 \text { tanda bukti pembayaran belum dilunasi bea } \\
\text { materai senilai } 24 \mathrm{x} \text { Rp. } 3 \cdot 000,00=\text { Rp. } 72.000,00\end{array}$ \\
\hline 2. & Nungkere & $\begin{array}{l}\text { 1. Realisasi penerimaan Kampung masih nihil. Hal ini disebabkan } \\
\text { penerimaan asli Kampung tidak dilaksanakan melalui rekening } \\
\text { Kampung sehingga kemungkinan terjadi kebocoran pendapatan } \\
\text { Kampung. } \\
\text { 2. Laporan pertanggungjawaban berkala belum dibuat pemeriksaan. }\end{array}$ \\
\hline 3. & Pepera & $\begin{array}{l}\text { 1. Terdapat selisih negatif antara saldo buku dengan saldo kas pada } \\
\text { saat pemeriksaan sebesar Rp. } 63.780 .946,00 \text { dikarenakan } \\
\text { terdapat pinjaman tunai dari beberapa orang } \\
\text { perangkat Kampung, belanja minyak tanah dan belanja } \\
\text { yang tidak terdeteksi dengan rincian sebagai berikut: } \\
\text { a. Pinjaman perangkat Kampung sebesar } \\
\text { Rp. } 21.105 .000,00 \text { a }\end{array}$ \\
\hline
\end{tabular}




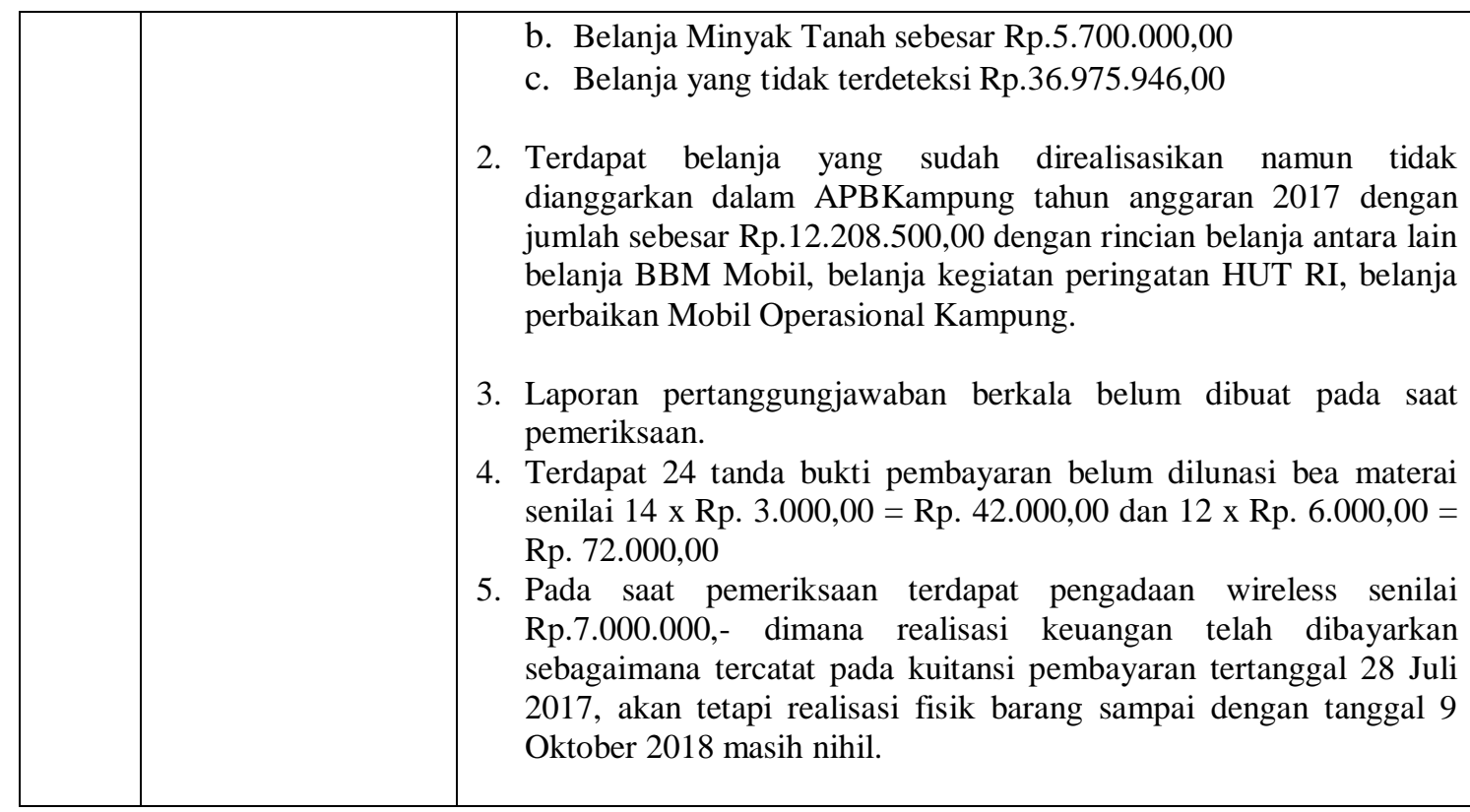

Sumber : LHP Inspektorat Kabupaten Yalimo tahun 2018.

Sedangkan penyimpangan pengelolaan Keuangan Kampung dimuat pada Laporan Hasil Pemeriksaan Inspektorat tahun anggaran 2018 kepada Kampung Trikora, Nungkere dan

\begin{tabular}{ccc} 
Pepera, & Nomor $:$ & \multicolumn{2}{c}{ 700/159/Inspek/2019 } \\
Tanggal 17 & Nopember & 2019 \\
memuat rincian & pemeriksaan & yang \\
disajikan dalam bentuk tabel 2. berikut : &
\end{tabular}

Tabel 2

Hasil Temuan Penyimpangan Pengelolaan Keuangan Kampung pada Tahun 2018 pada Kampung Distrik Benawa, Nungkere dan Pepera

\begin{tabular}{|c|c|c|}
\hline No. & Kampung & Hasil Temuan \\
\hline 1. & Trikora & $\begin{array}{l}\text { 1. Terdapat pembelian lahan untuk kas tanah Kampung sebesar } \\
\text { Rp.16.000.000,00 tidak masuk pada pos pengeluaran biaya } \\
\text { modal/pembangunan akan tetapi masuk pada pos pengeluaran } \\
\text { belanja bantuan sosial. Hal ini dikarenakan pada saat evaluasi } \\
\text { RAPBKampung terjadi perubahan yang diarahkan Bagian Tata } \\
\text { Pemerintahan yang semula berada pada pos belanja modal bergeser } \\
\text { menjadi pos bantuan sosial sehingga Inspektorat mengganggap hal } \\
\text { tersebut salah pos } \\
\text { anggaran. }\end{array}$ \\
\hline 2. & Nungkere & \\
\hline 3. & Pepera & $\begin{array}{l}\text { 1. Terdapat pengeluaran pembelian } 1 \text { (satu) unit mobil truck bekas } \\
\text { senilai Rp.74.285.000,00 yang tidak dimasukkan kedalam } \\
\text { pengeluaran belanja modal/pembangunan akan tetapi dimasukkan } \\
\text { ke } \\
\text { pengeluaran belanja tidak langsung. }\end{array}$ \\
\hline
\end{tabular}

Sumber : LHP Inspektorat Kabupaten Yalimo tahun 2019.

Berdasarkan data tersebut diatas dapat dipahami bahwa dalam kurun waktu 2015-2020 masih ditemukan pelanggaran yang tidak bisa dipertanggungjawabkan oleh KampungKampung se Distrik Benawa kecuali Kampung
Kamika yang dokumennya tidak ditemukan. Hal ini menggambarkan bahwa meskipun telah dibina secara minim oleh Subbag Otonomi Kampung dalam kurun waktu tersebut, tidak 
selalu paralel membawa perbaikan bagi tata kelola Keuangan Kampung

Mekanisme publikasi, pihak Kampung senantiasa menyampaikan laporan Keuangan Kampung kepada BAMUSKAM sebagai representasi dari masyarakat Kampung. Bagi masyarakat luas juga diberikan hak oleh Kampung untuk mengetahui laporan Keuangan Kampung sebagai pertanggungjawaban publik. Secara umum akuntabilitas Keuangan Kampung dalam kurun waktu 2015-2020 selama ditangani oleh Subbag Otonomi Kampung, masih ditemui sejumlah pelanggaran yang dilakukan oleh Kampung Distrik Benawa, Kampung Nungkere dan Kampung Pepera. Sedangkan akuntabilitas Keuangan Kampung Kamika tidak bisa diungkapkan dikarenakan data tidak ditemukan.

Kurun waktu 2015-2020 tidak ditemukan dokumen yang berkaitan dengan pertanggungjawaban Keuangan Kampung sehingga hasil wawancara yang digunakan sebagai acuan bagi pengungkapan akuntabilitas Keuangan Kampung. Berdasarkan hasil wawancara ditemukan bahwa secara prosedural masih belum sesuai dengan ketentuan yang diatur. Namun secara substansi sebagaimana data yang disampaikan kepada penulis dapat dilihat bahwa pengungkapan aktivitas keuangan telah diungkapkan secara jujur oleh masingmasing Kampung. Hal ini sejalan dengan prinsip akuntabilitas keuangan yang harus memiliki pengungkapan integritas keuangan dan ketaatan terhadap peraturan perundangundangan

\section{Akuntabilitas Manfaat}

Berdasarkan pendapat dari Tokoh Masyarakat Kampung dan Ketua BAMUSKAM se Distrik Benawa dapat dipahami bahwa masyarakat merasakan manfaat atas apa yang telah dikerjakan oleh pemerintah Kampung melalui program dan kegiatan yang dijalankan dalam membangun Kampung. Meskipun terdapat Kampung yang tidak membuat visi misi dan terdapat Kampung yang tidak melibatkan masyarakat dalam perencanaan pembangunan, akan tetapi hal tersebut tidak berpengaruh dengan pemenuhan kebutuhan masyarakat Kampung. Semestinya pengelolaan keuangan harus bertumpu pada kepentingan publik (public oriented). Hal ini tidak saja terlihat pada besarnya porsi pengalokasian anggaran untuk kepentingan publik, tetapi juga terlihat pada besarnya partisipasi masyarakat dalam perencanaan, pelaksanaan dan pengawasan keuangan

\section{Akuntabilitas Prosedur}

Akuntabilitas prosedur merupakan pertanggung jawaban mengenai apakah suatu prosedur penetapan dan pelaksanaan suatu kebijakan telah mempertimbangkan masalah moralitas, etika, kepastian hukum dan ketaatan pada keputusan politis untuk mendukung pencapaian tujuan akhir yang ditetapkan. Akuntabilitas prosedural ini mirip dengan akuntabilitas proses. Akuntabilitas prosedural akan dilihat sub dimensi mekanisme perencanaan, mekanisme pengadaan barang/jasa, mekanisme sistem akuntansi, prosedur administrasi dan mekanisme pengawasan. Mekanisme perencanaan pembangunan Kampung mengikuti pedoman pada Permendagri RI Nomor 66 Tahun 2017 tentang Perencanaan Pembangunan Kampung. Pada Permendagri tersebut mengamanatkan kepada Kampung untuk menyusun dokumen perencanaan pembangunan Kampung berupa dokumen Rencana Pembangunan Jangka Menengah Kampung (RPJM Kampung) sebagai penjabaran visi misi kepala Kampung dalam jangka waktu 5 (lima) tahun dan Rencana Kerja Pembangunan Kampung (RKPK) sebagai penjabaran dari RPJM Kampung untuk jangka waktu 1 (satu) tahun.Dokumen RPJM Kampung periode tahun 2015-2020 masing- masing kampung di distrik Benawa telah dibuat oleh 3 (tiga) kampung yaitu kampung Nungkere, kampung Trikora dan kampung Kamika dan 1 (satu) Kampung tidak membuat dokumen RPJM Kampung yaitu Kampung Pepera. Sedangkan Dokumen RKP Kampung periode tahun 20152020, setiap tahunnya telah dibuat oleh seluruh kampung di distrik Benawa

Jika dilihat dari keterlibatan masyarakat dan aparatur Kampung dalam perencanaan pembangunan bisa dikategorikan berpartisipasi aktif dalam merencanakan pembangunan Kampung. Antusiasme masyarakat untuk menghadiri kegiatan musrenbang kampung tergolong baik sebagaimana ditemukan pada daftar jumlah yang hadir mengikuti musrenbang kampung. Bahkan setiap tahunnya rata-rata dari jumlah yang hadir berkisar $80 \%$ dari daftar yang diundang dan telah mempertimbangkan keterwakilan perempuan sebesar $30 \%$ kecuali Kampung Kamika yang harus menunggu kehadiran masyarakat berada di Kamika pada bulan April.

Mekanisme pengadaan barang/jasa di Kampung mengikuti pedoman yang diatur pada Permendagri RI Nomor 37 Tahun 2017 tentang Pedoman Pengelolaan Keuangan Kampung yang masih menggunakan cara konvensional mengenai tata cara pengadaan barang/jasa yang 
dilakukan secara swakelola dan hanya melengkapi tanda bukti pembelian serta mengikuti harga kewajaran yang berlaku di pasar. Pada regulasi tersebut tidak memuat secara eksplisit mengenai tata cara pengadaan barang/jasa di Kampung sehingga Kampung mengikuti pola kebiasaan yang berlaku setiap tahunnya.

Berdasarkan ketentuan tersebut sistem akuntansi Keuangan Kampung masih tergolong sederhana tanpa menginduk pada sistem akuntansi pemerintahan daerah. Dalam hal menjalankan sistem akuntansi Keuangan Kampung, pencatatan Keuangan Kampung dibukukan pada :

1. Buku kas umum;
2. Buku kas pembantu perincian obyek pengeluaran;

3. Bukti atas penyetoran $\mathrm{PPN} / \mathrm{PPh}$ ke Kas Negara.

Jika dilihat dari laporan hasil pemeriksaan Inspektorat dalam kurun waktu 2015-2020, ditemukan bahwa kelengkapan prosedur administrasi Keuangan Kampung tidak dilengkapi oleh Kampung- Kampung se Distrik Benawa. Berdasarkan Laporan Hasil Pemeriksaan Inspektorat tahun anggaran 2017 kepada Kampung Trikora, Nungkere, Pepera dan Kamika, Nomor : 700/123/Inspek/2018 tanggal 29 Oktober 2018 memuat rincian pemeriksaan yang disajikan dalam bentuk tabel 3. di bawah ini :

Tabel 3.

Hasil Temuan Kelengkapan Prosedur Administrasi Pengelolaan Keuangan Kampung pada Tahun 2018 pada Kampung-Kampung se Distrik Benawa

\begin{tabular}{|c|c|c|c|c|c|}
\hline \multirow[t]{2}{*}{ No. } & \multirow[t]{2}{*}{ Uraian } & \multicolumn{4}{|c|}{ Kampung } \\
\hline & & Pepera & Nungkere & Trikora & Kamika \\
\hline 1. & SK Bendahara Kampung & Ada & Ada & Ada & Ada \\
\hline 2. & Buku Kas Umum & Ada & Ada & Ada & Ada \\
\hline 3. & Buku Bantu Per Pos Pengeluaran & Ada & Ada & Ada & Ada \\
\hline 4. & Register SPP & Tidak Ada & Tidak Ada & Tidak Ada & Ada \\
\hline 5. & Register SPM & Tidak Ada & Tidak Ada & Tidak Ada & Ada \\
\hline 6. & Register SP2D & Tidak Ada & Tidak Ada & Tidak Ada & Ada \\
\hline 7. & Buku Bank & Tidak Ada & Tidak Ada & Tidak Ada & Ada \\
\hline 8. & $\begin{array}{l}\text { Pemeriksaan Atasan } \\
\text { Langsung }\end{array}$ & Tidak Ada & Tidak Ada & Tidak Ada & Ada \\
\hline 9. & SPJ & Tidak Ada & Tidak Ada & Tidak Ada & Ada \\
\hline 10. & Brankas & Tidak Ada & Tidak Ada & Tidak Ada & Ada \\
\hline 11. & Pemeriksaan APIP & Ada & Ada & Ada & Ada \\
\hline 12. & NPWP & Tidak Ada & Ada & Tidak Ada & - \\
\hline
\end{tabular}

Sumber : LHP Inspektorat Kabupaten Yalimo tahun 2019.

Sedangkan kelengkapan administrasi pengelolaan Keuangan Kampung sebagaimana dimuat pada Laporan Hasil Pemeriksaan Inspektorat tahun anggaran 2018 kepada Kampung Trikora, Nungkere dan Pepera,
Nomor : 700/159/Inspek/2019 Tanggal 17 Nopember 2019 memuat rincian pemeriksaan yang disajikan dalam bentuk tabel 4. di bawah ini :

Tabel 4.

Hasil Temuan Kelengkapan Prosedur Administrasi Pengelolaan Keuangan Kampung pada Tahun 2019 pada Kampung Distrik Benawa, Nungkere dan Pepera

\begin{tabular}{|c|c|c|c|c|}
\hline \multirow{2}{*}{ No. } & \multirow{2}{*}{ Uraian } & \multicolumn{3}{|c|}{ Kampung } \\
\cline { 3 - 5 } & & Pepera & Nungkere & Trikora \\
\hline 1. & SK Bendahara Kampung & Ada & Ada & Ada \\
\hline 2. & Buku Kas Umum & Ada & Ada & Ada \\
\hline
\end{tabular}




\begin{tabular}{|r|c|c|c|c|}
\hline 3. & Buku Bantu Per Pos Pengeluaran & Ada & Ada & Ada \\
\hline 4. & Register SPP & Ada & Ada & Ada \\
\hline 5. & Register SPM & Ada & Ada & Ada \\
\hline 6. & Register SP2D & Ada & Ada & Ada \\
\hline 7. & Buku Bank & Ada & Ada & Ada \\
\hline 8. & Pemeriksaan Kas 3 Bulan & Tidak & Tidak Ada & Ada \\
& & Ada & & Ada \\
\hline 9. & SPJ & Ada & Ada & Tidak Ada \\
\hline 10. & Brankas & Tidak & Ada & Ada \\
\hline 11. & Pemeriksaan APIP & Ada & Ada & Ada \\
\hline 12. & NPWP & Ada & Ada & \\
\hline
\end{tabular}

Sumber : LHP Inspektorat Kabupaten Yalimo tahun 2019.

Dalam kurun waktu 2015-2020 masih ditemukan pelanggaran prosedur administrasi Keuangan Kampung yang dilakukan oleh Kampung-Kampung se Distrik Benawa kecuali Kampung Kamika pada tahun 2020 yang dokumennya tidak ditemukan. Hal ini menggambarkan bahwa meskipun telah dibina secara minim oleh Bidang Pemerintahan Kampung dalam kurun waktu tersebut, tidak selalu linier membawa perbaikan bagi tata kelola Keuangan Kampung. ketaatan terhadap prosedur administrasi Keuangan Kampung sangat ditentukan oleh kesadaran aparatur Kampung itu sendiri. Fungsi pembina hanya sebatas membimbing dan membangun kesadaran kepada masing-masing Kampung untuk mengikuti ketentuan yang ada.

Mekanisme pengawasan pengelolaan Keuangan Kampung yang dijalankan oleh pemerintah Kampung mengacu pada Permendagri RI Nomor 37 Tahun 2017 tentang Pengelolaan Keuangan Kampung. Mekanisme pengawasan pembangunan Kampung di Kampung-Kampung se Distrik Benawa selalu dimonitor oleh Badan Permusyawaratan Kampung maupun masyarakat baik melalui mekanisme pertanggungjawaban pengelolaan Keuangan Kampung setiap tahunnya bertempat di Kantor BAMUSKAM maupun di Kantor Pemerintah Kampung. Bahkan mekanisme pengawasan tersebut bisa langsung dikontrol masyarakat pada saat kegiatan dilapangan telah dimulai.

Berdasarkan hasil wawancara dan telaah dokumen yang dilakukan penulis didapati bahwa Kampung Pepera tidak membuat RPJM Kampung, Kampung Kamika tidak melibatkan masyarakat dalam perencanaan pembangunan, Kampung Trikora tidak melibatkan BAMUSKAM dalam pelaksanaan APBKampung dan tidak membuat dokumen keuangan dalam kurun waktu 2015-2020 bagi Kampung- Kampung se distrik Benawa sebagaimana diungkap berdasarkan Hasil Laporan Pemeriksaaan Inspektorat Nomor : 700/123/Inspek/2018 tanggal 29 Oktober 2019 dan Nomor : 700/159/Inspek/2019 Tanggal 17 Nopember 2019. Secara umum akuntabilitas prosedur masih diwarnai dengan ketidaktaatan aparatur Kampung untuk mengikuti prosedur yang telah digariskan pemerintah. Padahal akuntabilitas prosedur menekankan pada pertanggungjawaban mengenai apakah suatu prosedur penetapan dan pelaksanaan suatu kebijakan telah mempertimbangkan masalah moralitas, etika, kepastian hukum dan ketaatan pada keputusan politis untuk mendukung pencapaian tujuan akhir yang ditetapkan

Faktor Pendukung dan Penghambat Akuntabilitas Pengelolaan Keuangan kampung Dalam Pemberdayaan Masyarakat di Distrik Benawa Kabupaten Yalimo Provinsi Papua.

\section{Faktor Pendukung}

Faktor pendukung merupakan instrumen yang dapat menunjang suatu Akuntabilitas Pengelolaan Keuangan kampung Dalam Pemberdayaan Masyarakat, seperti yang didapatkan penulis saat melakukan penelitian diantaranya ada beberapa faktor yang menjadi aspek dalam keberhasilan pelaksanaan kegiatan, yaitu Lingkungan Organisasi dan Lingkungan Pekerja.

\section{Lingkungan Organisasi}

Faktor pendukung dari aspek lingkungan organisasi pada Dinas Pemberdayaan Masyarakat Pemerintahan Kampung Kabupaten Yalimo merupakan lingkungan yang dibangun di dinas tersebut baik dari sisi etika maupun 
sistem kerja, untuk mengetahui itu penulis melakukan wawancara dengan Kepala Dinas Pemberdayaan Masyarakat Pemerintahan Kampung Kabupaten Yalimo pada tanggal 20 Juni 2020. Organisasi merupakan suatu koneksitas manusia yang kompleks dan dibentuk untuk tujuan tertentu, dimana hubungan antara anggotanya bersifat resmi (impersonal), ditandai oleh aktivitas kerjasama, terintegrasi dalam lingkungan yang lebih luas, memberikan pelayanan dan produk tertentu dan tanggungjawab kepada hubungan dengan lingkungannya.

\section{Lingkungan Pekerja}

Faktor pendukung dari aspek Lingkungan pekerja yang merupakan karakter pegawai yang berada di Dinas Pemberdayaan Masyarakat Pemerintahan Kampung Kabupaten Yalimo. lingkungan pekerja yang merupakan karakter pegawai yang berada di Dinas Pemberdayaan Masyarakat Pemerintahan Kampung Kabupaten Yalimo memiliki tingkat kepatuhan yang baik walaupun terkadang masih ada ego yang dikedepankan akan tetapi dapat diatasi dengan sikap kepemimpinan atasan mereka.

\section{Faktor Penghambat}

Faktor penghambat merupakan faktor yang sangat mempengaruhi dalam pelaksanaan kegiatan dilapangan, hal ini dikaitkan dengan Akuntabilitas Pengelolaan Keuangan kampung Dalam Pemberdayaan Masyarakat Di Distrik Benawa Kabupaten Yalimo Provinsi Papua ada beberapa faktor yang menjadi aspek dalam menghambat pelaksanaan kegiatan, diantaranya Sumber Daya Manusia, Anggaran, sarana dan prasarana.

\section{Sumber Daya Manusia}

Salah satu faktor penghambat adalah ketersediaan sumber daya manusia yang memadai baik dari segi kuantitas maupun kualitasnya. Dinas Pemberdayaan Masyarakat Pemerintahan Kampung Kabupaten Yalimo sebagai sebagai leading sektor dalam Akuntabilitas Pengelolaan Keuangan kampung. jumlah Pegawai Negeri Sipil (PNS) yang dimiliki oleh Dinas Pemberdayaan Masyarakat dan Pemerintahan Kampung Kabupaten Yalimo masih sangat terbatas baik dari degi kuantitas maupun kulaitasnya.

\section{Anggaran}

Salah satu faktor yang juga menjadi penghambat Dinas Pemberdayaan Masyarakat Pemerintahan Kampung Kabupaten Yalimo terkait stadar akuntabilitas pengelolaan keuangan yang telah ditetapkan karena keterbatasan anggaran. Selain itu, keterbatasan anggaran merupakan faktor yang paling mendasar yang menjadi penyebab tidak adanya pengawasan yang ketat terhadap pengelolaan keuangan kampung di Distrik Benawa Kabupaten Yalimo

Komposisi anggaran yang diberikan ke Dinas Pemberdayaan Masyarakat Pemerintahan Kampung Kabupaten Yalimo sesuai dengan peraturan Menteri keuangan berkisar pada $4 \%$ dari total pagu DAU yang ada dengan begitu penulis menyimpulkan bahwa komposisi anggaran yang diberikan kepada Dinas Pemberdayaan Masyarakat Pemerintahan Kampung Kabupaten Yalimo masih berkisar dibawah $4 \%$ anggaran dari total DAU.

\section{Sarana dan Prasarana}

Sarana dan prasarana faktor penghambat dan merupakan hal yang juga mendasar dalam Akuntabilitas Pengelolaan Keuangan kampung Dalam Pemberdayaan Masyarakat Di Distrik Benawa Kabupaten Yalimo Provinsi Papua, dimana sarana dan prasana dapat mendukung segala aktifitas kegiatan, namun pada kenyataannya sarana dan prasarana Dinas Pemberdayaan Masyarakat Pemerintahan Kampung Kabupaten Yalimo belum memadai sehingga pekerjaan yang dihasilkan selalu saja tidak maksimal. Sarana dan prasarana yang dimiliki Dinas Pemberdayaan Masyarakat Pemerintahan Kampung Kabupaten Yalimo kurang memadai, hal ini menjadi tidak maksimal terhadap pelaksanaan Akuntabilitas Pengelolaan Keuangan kampung Dalam Pemberdayaan Masyarakat Di Distrik Benawa Kabupaten Yalimo Provinsi Papua.

\section{Upaya Mengatasi Faktor Penghambat Akuntabilitas Pengelolaan Keuangan Kampung Dalam Pemberdayaan Masyarakat Di Distrik Benawa Kabupaten Yalimo Provinsi Papua}

Berdasarkan pengamatan dan hasil wawancara sebelumnya terhadap upaya yang dilakukan dalam mengatasi faktor penghambat Akuntabilitas Pengelolaan Keuangan kampung Dalam Pemberdayaan Masyarakat Di Distrik Benawa Kabupaten Yalimo Provinsi Papua dengan melakukan langkah-langkah yaitu sebagai berikut:

\section{Peningkatan Kualitas Sumber Daya Manusia \\ Dalam mengatasi faktor penghambat,} Dinas Pemberdayaan Masyarakat Pemerintahan 
Kampung Kabupaten Yalimo dalam Akuntabilitas Pengelolaan Keuangan kampung Dalam Pemberdayaan Masyarakat Di Distrik Benawa yang mencakup peningkatan kualitas sumber daya manusia, dengan melihat apa yang Dinas Pemberdayaan Masyarakat Pemerintahan Kampung Kabupaten Yalimo dalam peningkatan kualitas sumber daya manusia pegawainya. peningkatan kualitas sumber daya manusia, dengan melihat apa yang dilakukan Dinas Pemberdayaan Masyarakat Pemerintahan Kampung Kabupaten Yalimo dalam peningkatan kualitas sumber daya manusia pegawainya sudah sangat baik dan terencana hal ini dibuktikan dengan tiap tahunnya mengutus dari personilnya untuk mengikut bimbingan dan diklat teknis khususnya pada bidang pengawasan.

\section{Penambahan Komposisi Anggaran}

Dalam mengatasi faktor penghambat Akuntabilitas Pengelolaan Keuangan kampung Dalam Pemberdayaan Masyarakat Di Distrik Benawa Kabupaten Yalimo Provinsi Papua yang mencakup penambahan komposisi anggaran, dengan melihat bagaimana upaya Dinas Pemberdayaan Masyarakat Pemerintahan Kampung Kabupaten Yalimo dalam penambahan anggaran khususnya anggaran yang memfokuskan pada pengawasan pengelolaan keuangan kampung Di Distrik Benawa. penambahan komposisi anggaran Dinas Pemberdayaan Masyarakat Pemerintahan Kampung Kabupaten Yalimo khususnya anggaran yang memfokuskan pada pengawasan pengelolaan keuangan kampung belum berjalan dengan maksimal hal ini dikarenakan upaya yang dilakukan tidak menambah komposisi anggaran yang ditetapkan melainkan untuk melakukan penghematan.

\section{Pengadaan Sarana dan Prasarana}

Dalam mengatasi faktor penghambat Akuntabilitas Pengelolaan Keuangan kampung Dalam Pemberdayaan Masyarakat Di Distrik Benawa Kabupaten Yalimo Provinsi Papua yang mencakup pengadaan sarana dan prasarana serta juga melihat sarana dan prasaran apa yang dibutuhkan oleh Dinas Pemberdayaan Masyarakat Pemerintahan Kampung Kabupaten Yalimo dalam menunjang pelaksanaan kegiatan dilapangan.

\section{KESIMPULAN DAN SARAN}

\section{Kesimpulan}

Berdasarkan hasil pembahasan yang telah dibahas pada Bab sebelumnya, maka kesimpulan yang dapat ditarik sebagai berikut :

1. Akuntabilitas Pengelolaan Keuangan Kampung yang didekati dengan 3 (tiga) aspek akuntabilitas yaitu Akuntabilitas keuangan, Akuntabilitas Manfaat, dan Akuntabilitas Prosedur ditemukan bahwa secara prosedural masih belum sesuai dengan ketentuan yang diatur. Namun secara substansi sebagaimana data yang disampaikan kepada penulis dapat dilihat bahwa pengungkapan aktivitas keuangan telah diungkapkan secara jujur oleh masingmasing Kampung. Hal ini sejalan dengan prinsip akuntabilitas keuangan yang harus memiliki pengungkapan integritas keuangan dan ketaatan terhadap peraturan perundangundangan.

2. Faktor Pendukung. Ditinjau dari Lingkungan Organisasi, faktor pendukung ditandai oleh aktivitas kerjasama, terintegrasi dalam lingkungan yang lebih luas, memberikan pelayanan dan produk tertentu dan tanggungjawab kepada hubungan dengan lingkungannya dan dari sisi lingkungan pekerja yang merupakan karakter pegawai yang berada di Dinas Pemberdayaan Masyarakat Pemerintahan Kampung Kabupaten Yalimo memiliki tingkat kepatuhan yang baik walaupun terkadang masih ada ego yang dikedepankan akan tetapi dapat diatasi dengan sikap kepemimpinan atasan mereka.

Sementara itu, faktor penghambat adalah ketersediaan sumber daya manusia yang memadai baik dari segi kuantitas maupun kualitasnya. Dinas Pemberdayaan Masyarakat Pemerintahan Kampung Kabupaten Yalimo sebagai sebagai leading sektor dalam Akuntabilitas Pengelolaan Keuangan kampung, selanjutnya yang juga merupakan faktor penghambat adalah komposisi anggaran yang diberikan kepada Dinas Pemberdayaan Masyarakat Pemerintahan Kampung Kabupaten Yalimo masih berkisar dibawah 4\% anggaran dari total DAU, serta faktor pengambat lainnya adalah 
Sarana dan prasarana yang dimiliki

Dinas Pemberdayaan Masyarakat Pemerintahan Kampung Kabupaten Yalimo kurang memadai, hal ini menjadi tidak maksimal terhadap pelaksanaan Akuntabilitas Pengelolaan Keuangan kampung Dalam Pemberdayaan Masyarakat Di Distrik Benawa Kabupaten Yalimo Provinsi Papua

3. Upaya yang dilakukan dalam mengatasi faktor penghambat akuntabilias keuangan Keuangan kampung salah satunya adalah Peningkatan kualitas sumber daya manusia, dengan melihat apa yang dilakukan Dinas Pemberdayaan Masyarakat Pemerintahan Kampung Kabupaten Yalimo dalam peningkatan kualitas sumber daya manusia pegawainya sudah sangat baik dan terencana hal ini dibuktikan dengan tiap tahunnya mengutus dari personilnya untuk mengikut bimbingan dan diklat teknis khususnya pada bidang pengawasan selain itu penambahan komposisi anggaran Dinas Pemberdayaan Masyarakat Pemerintahan Kampung Kabupaten Yalimo khususnya anggaran yang memfokuskan pada pengawasan pengelolaan keuangan kampung belum berjalan dengan maksimal hal ini dikarenakan upaya yang dilakukan tidak menambah komposisi anggaran yang ditetapkan melainkan untuk melakukan penghematan serta pengadaan sarana dan prasarana yang dibutuhkan oleh Dinas Pemberdayaan Masyarakat Pemerintahan Kampung Kabupaten Yalimo sebagai penunjang pelaksanaan kegiatan dilapangan, sangatlah banyak hal ini harus didukung dan disuport agar pengawasan demi terciptanya akuntabilitas pengelolan keuangan kampung dapat terlaksana dengan baik.

\section{Saran}

Akuntabilitas pengelolaan keuangan Kampung seringkali dihadapkan dengan berbagai kendala dalam upaya melakukan pembimbingan, pendampingan, pengarahan maupun supervisi bagi aparatur Kampung, untuk itu saran yang dapat di sampaikan melalui penelitian ini antara lain :

1. Akuntabilitas Pengelolaan Keuangan Kampung yang didekati dengan 3 (tiga) aspek akuntabilitas yaitu Akuntabilitas keuangan, Akuntabilitas Manfaat, dan Akuntabilitas Prosedur maka dari itu penulis memberikan saran agar pengungkapan aktivitas keuangan seharusnya diungkapkan secara jujur oleh masing-masing Kampung dan tepat waktu sehingga taat kepada indikator pengeloaan keuangan kampung tersebut.

2. Ketersediaan sumber daya manusia yang memadai baik dari segi kuantitas maupun kualitasnya dengan kebutuhan organisasi tersebut yaitu perlunya penambahan dan penempatan personil yang tepat dengan istilah yang biasa didengar adalah the right man on the the right place sealin itu agar komposisi anggaran yang diberikan kepada Dinas Pemberdayaan Masyarakat Pemerintahan Kampung Kabupaten Yalimo dalam hal ini Akuntabilitas Pengelolaan Keuangan kampung Dalam Pemberdayaan Masyarakat Di Distrik Benawa Kabupaten Yalimo Provinsi Papua dapat diberikan sesuai dengan ketentuan yang telah ditetapkan yaitu sebesar $12 \%$ dari total DAU serta agar Sarana dan prasarana yang dimiliki Dinas Pemberdayaan Masyarakat Pemerintahan Kampung Kabupaten Yalimo dapat memadai yaitu perlunya inventarisir kendaraan yang sudah rusak dan menggantinya dengan kondisi yang lebih baik.

3. Peningkatan kualitas sumber daya manusia, yang dilakukan Dinas Pemberdayaan Masyarakat Pemerintahan Kampung Kabupaten Yalimo dalam peningkatan kualitas sumber daya manusia pegawainya yaitu perlunya bukan hanya mengikutsertakan dalam diklat-diklat teknis melainkan menambah komposisi personal secara kuantitas dengan memeberikan pertimbangan kepada Bapak Bupati untuk menepatkan orang-orang yang lebih berkompeten dan profesioanal pada dinas tersebut hal yang senada juga penulis menyarankan agar agar penambahan komposisi anggaran Dinas Pemberdayaan Masyarakat Pemerintahan Kampung Kabupaten Yalimo khususnya anggaran yang memfokuskan pada pengawasan melekat dapat bertambah yaitu dengan 
melakukan konsultasi dengan cara memeberikan proposal kepada pihak kementrian yang berada di pusat guna mendapatkan dana segar serta pengadaan sarana dan prasarana yang dibutuhkan oleh Dinas Pemberdayaan Masyarakat Pemerintahan Kampung Kabupaten Yalimo sebagai penunjang pelaksanaan kegiatan dilapangan dapat terpenuhi perlunya pengalokasian anggaran yang terfokus pada belanja modal dalam bentuk barang.

\section{DAFTAR PUSTAKA}

Adisasmita, Rahardjo, 2011, Manajemen Pemerintah Daerah, Penerbit : Graha Ilmu, Yogyakarta.

Arikunto, Suharsimi, 2006, Prosedur Penelitian Suatu Pendekatan Praktis, Penerbit : Rineka Cipta, Jakarta.

----------, 2010, Prosedur Penelitian Suatu Pendekatan Praktis, Penerbit : Rineka Cipta, Jakarta.

Djaenuri, Aries, 2012, Hubungan Keuangan Pusat - Daerah, Penerbit : Ghalia Indonesia, Bogor.

Djalil, Rizal, 2014, Akuntabilitas Keuangan Daerah Implementasi Pasca Reformasi, Penerbit : Wahana Semesta Intermedia, Jakarta.

Effendy, Khasan, 2010, Penguatan Pemerintahan Desa, Penerbit : Indra Prahasta, Bandung.

Gunawan, Adi, 2002, Kamus Praktis Ilmiah Populer, Penerbit : Kartika, Surabaya.

Halim, Abdul dan Muhammad Iqbal, 2012, Pengelolaan Keuangan Daerah Seri Bunga Rampai Manajemen Keuangan Daerah, Penerbit : UPP STIM YKPN, Yogyakarta.

Harian Papua Pos,7 Bulan Penjara, http://www.papuapos.co.id/berita/detail/ kamtibmas/6462--divonis-7-bulanpenjara.html, diunduh 21 Januari 2020.

Johan, Djohermansyah, 2014, Merajut Otonomi Daerah Pada Era Reformasi, Penerbit : IKAPTK, Jakarta.

Lembaga Administrasi Negara dan BPKP, 2000, Modul 1 Akuntabilitas dan Good Governance, Penerbit : LAN Jakarta

Mardiasmo, 2002, Otonomi Dan Manajemen Keuangan Daerah, Penerbit : Andi, Yogyakarta.

Maryani, Dedeh, 2014, Manajemen Keuangan Daerah, Penerbit : IPDN Press, Bandung.
Mulyadi, Mohammad, 2014, Metode Penelitian Praktis : Kuantitatif Dan Kualitatif, Penerbit : Publica Institute, Jakarta.

--------, 2015, Desa Dinamika Kehidupan Sosial Di Desa, Penerbit : Publica Press, Jakarta.

Nurcholis, Hanif, 2011, Pertumbuhan Dan Penyelenggaraan Pemerintahan Desa, Penerbit : Erlangga, Jakarta.

Perangkat Desa/kampung Cemas Tunggu Pencairan, Harian Papua Pos, Jum'at, 10 Juli 2019, hlm.11 Rp. 97 Juta Tak Masuk Kas Desa/kampung, Harian Papua Pos, Jum'at, 1 Oktober 2019, hlm.8.

Peraturan Daerah Yalimo Nomor 08 Tahun 2013 Tentang Keuangan Kampung

Peraturan Bupati Yalimo Nomor 40 Tahun 2017 Tentang Penjabaran Tugas Pokok Dan Fungsi Dinas Pemberdayaan Masyarakat Pemerintahan Kampung.

Sedarmayanti, 2012, Good Governance "Kepemerintahan Yang Baik". Dalam Rangka Otonomi Daerah Upaya Membangun Organisasi Efektif Dan Efisiensi Melalui Restrukturisasi Dan Pemberdayaan, Penerbit : Mandar Maju, Bandung.

Sedarmayanti dan Syarifudin Hidayat, 2011, Metode Penelitian, Penerbit : Mandar Maju, Bandung.

Setyono, Budi, 2014, Pemerintahan Dan Manajemen Sektor Publik PrinsipPrinsip Manajemen Pengelolaan Negara Terkini, Penerbit : CAPS (Center of Academic Publishing Service), Yogyakarta.

Simangunsong, Fernandes, 2014, Perubahan Status Desa Menjadi Kelurahan, Penerbit : IPDN Press, Bandung.

Soekanto, Soerjono, 2007, Sosiologi Suatu Pengantar, Penerbit : Raja Grafindo Persada, Jakarta.

Soleh, Chobib dan Heru Rochmansjah, 2010, Pengelolaan Keuangan Dan Aset Daerah, Penerbit : Fokus Media Bandung.

Sugiyono, 2008, Memahami Penelitian Kualitatif, Penerbit : Alfabeta, Bandung.

Sugiyono, 2010, Metode Penelitian Kuantitatif Kualitatif Dan R\&D,Penerbit : Alfabeta, Bandung.

, 2011, Metode Penelitian Kuantitatif Kualitatif Dan R\&D, Penerbit : Alfabeta, Bandung.

2014, Metode Penelitian Kuantitatif Kualitatif Dan R\&D, Penerbit : Alfabeta, Bandung. 
Supriatna, Tjahya, 2010, Sistem Pemerintahan Desa, Penerbit : Indra Prahasta, Bandung.

Tahir, M. Irwan, 2012, Sejarah Perkembangan Desa Di Indonesia : Demi Masa Lalu, Masa Kini dan Bagaimana Masa Depannya, Jurnal Ilmu Pemerintahan Edisi 38 Tahun 2012, Penerbit : MIPI, Jakarta.

Undang-Undang Dasar RI 1945.

Undang-Undang RI Nomor 06 Tahun 2014 Tentang Desa

Undang-Undang RI Nomor 23 Tahun 2014 Tentang Pemerintahan Daerah
Wasistiono, Sadu, 2012, Telaah Kritis Terhadap Rancangan Undang-Undang Tentang Desa, Jurnal Ilmu Pemerintahan Edisi 38 Tahun 2012, Penerbit : MIPI, Jakarta.

Widjaja, HAW, 2010, Otonomi Desa Merupakan Otonomi Yang Asli Bulat Dan Penuh, Penerbit : Rajawali Press, Jakarta.

Yani, Ahmad, 2013, Hubungan Keuangan Antara Pemerintah Pusat Dan Daerah Di Indonesia, Penerbit : Rajawali Pers, Jakarta. 